\title{
Finding a Balance in Education: Immigration, Diversity, and Schooling in Urban America, 1880-1900
}

\author{
By Theodore G. Zervas*
}

\begin{abstract}
When looking at the historical past, questions of diversity and school reform seem to go hand in hand. The presence of diverse communities in American urban schools has helped foster a change in traditional educational practices and policies. At times, the goal for these communities was to be given their just share of receiving a fair, equitable, and democratic education. However, when evaluating America's historical timeline, issues of diversity in American urban schools emerge when major social and political events impact aspects of American social life. The period 1880-1900 saw vast numbers of immigrants, mostly from Europe, settling in America's metropolitan cities. Some of these immigrants had aspirations of beginning a new life in the United States, while others sought to work hard, make a bit of money and return back home with their newfound wealth. Those that did settle brought with them their customs and traditions, languages and religions as well as their unique views on education. This essay explores how several immigrant groups in the United States reacted to the already present modes of schooling, and how American schools responded to the educational needs and educational demands of these groups.
\end{abstract}

Keywords: American education, American schools in the late $19^{\text {th }}$ century, immigrant education

\section{Introduction}

To a large degree, much of the American educational past has been confronted with issues of diversity in its schools. When looking at the historical past, questions of diversity and school reform seem to go hand in hand, and it is the presence of diverse communities that help foster a change in traditional educational practices and policies. At times, the goal of these communities is to be given their fair share in receiving an equitable and democratic education. However, when evaluating America's historical timeline, issues of diversity in American schools emerge when major events impact most aspects of American life. The period 1880-1900 saw vast numbers of immigrants (mostly from Europe) settle in the United States. Many had aspirations in beginning a new life in the United States while others, as Gary Gerstle asserts, "were sojourners in a harsh capitalist land, hoping to cut the best deal they could and then leave" (Gerstle, 1997). Those that settled in the United States brought with them their customs and traditions, languages and religions as well as their unique views on education. This essay explores how several immigrant groups reacted to the already present modes of schooling in

\footnotetext{
${ }^{*}$ Associate Professor \& MAT Coordinator, North Park University in Chicago, Illinois, USA.
} 
the United States, and how American schools responded to the educational needs and educational demands of these groups.

\section{Industrialization and Progressivism}

By the early 1880's America moved beyond the notion of the common school and into the age of progressive education. Progressivism helped motivate a change from traditional modes of education to more contemporary topics of study. Beginning in 1893, the National Education Association proposed a broadly based high school curriculum that sought to prepare students for college while at the same time train students for a modern and constantly changing world. Educationalists began to re-think what subjects would be taught in schools. Most of the debate focused on two contending beliefs: 1. the traditional or orthodox belief that emphasized humanist and classics education, and 2. the progressive or revisionist school that considered the interest of the child (Tyack, 1995). Industrialization, immigration, modernization and a growing American economy demanded more workers, more production and more consumers to help sustain American economic and social growth. Evidence of American achievement was visible at every hand. Trains ran, and the railways were spectacular symbols of a vast revolutionary wealth that included, steel mills, textiles factories, steamboats and the telegraph. The United States saw a rise in capital, and the sensational display of modern bridges, and colossal buildings.

Across the Atlantic, in Europe, political, social, and economic instability left a European population uncertain of its future. Indeed, Europeans still enjoyed the wealth they reaped from the Industrial Revolution and from their imperial colonies in Africa and Asia. However, nationalist movements, a reorganization of borders, a rigid class structure and a rethinking of political systems led many Europeans to look elsewhere for economic, social and political stability. John Bodnar states,

Traditionally the impetus for American immigration has been linked to the disparity between improving standard of living in America and impoverishment of pre-modern societies throughout the world. Stimulated by improvements in transportation which lowered the real cost of moving freight and passengers and which facilitated the expansion of both domestic and foreign markets, American economic growth Accelerated during the half-century after 1870 (Bodnar, 1987).

For the most part, immigration from 1880-1900 was predominantly an urban American phenomenon. Paula S. Fass finds that, "Decade after decade in the nineteenth century, vast numbers of immigrants arrived in American ports, three-fourths of them at New York. Between 1860 and 1890, thirteen and onehalf million new immigrants arrived" (Fass, 1989). American cities like New York (which had traditionally been the first stop for immigrants) Baltimore, 
Boston, Chicago, Cincinnati, Milwaukee, and St. Louis, welcomed new immigrants in order to help facilitate American economic prosperity. The new immigrant groups strove to maintain their traditional customs while adopting American cultural values. Some Americans understood that education was not intended to assimilate immigrant groups, but to help these groups cope with learning the cultural and social norms of their adopted new country while maintaining their European traditions. David Tyack says, "Some educators used draconian measures to assimilate the newcomers, while others, believing that coercion was counterproductive, tried to graft the branches of many cultures onto the trunk of Anglo-American society" (Tyak, 1993). Others like Michael Olneck assert that American schools through civics education programs intentionally tried to assimilate immigrant children into mainstream America or that

The Americanization movement and civics education can be interpreted as symbolic action sanctioning a particular status order with certain definitions and interpretations of social phenomena. The purpose most commonly attributed to its transformation of immigrants (Olneck, 1989).

Many immigrant communities saw American education as a devise for assimilation and reacted by taking measures to protect their cultural and linguistic identities.

\section{Early Immigrant Reaction to American Education}

By the late 1800s America's schools were flooded with immigrant children. American schools were left with the difficult task of educating a predominantly non-English speaking population. In New York City in 1890, the foreign born population was approximately 639,943 when the cities entire population was $1,515,301$. In the 1800 s 200,000 immigrants entered the United States, where five years later in 1885, 800,000 immigrants had made the U.S. their home.

In Chicago's public schools, Polish, German, Swedish, Norwegian, and Czech languages were taught to elementary and secondary level students. Between 1860 and 1880 Chicago Public School's population quadrupled, to more than 30,000 outpacing the city's growth. As the immigrant population grew, schools were called upon to assimilate these new immigrant groups. American history, civics, and English classes were given more attention, than other subjects, to hasten the process of assimilation. Immigrant parents however fought back demanding that their children maintain their native languages while learning English and American History. At times various immigrant groups competed with one another to have their languages taught over other immigrant languages. This often occurred when space and money was limited in the school system for foreign language instruction (Zimmerman, 2002). Groups that felt that their language was being neglected responded by 
using the American principal of democracy and equity-contending that if one foreign language was being taught than their language needed to be taught as well (Zimmerman, 2002). In other instances immigrants went knocking on the door of their local alderman demanding that their language be taught at their local school.

It is no surprise that many immigrants communities were vibrant, organized, and ambitious in their campaigns to have their language taught to their progeny. They often used several channels to get their message across and often gained the support of local political leaders and community members. Through local ethnic papers, editorials and opinions were written explaining why their native-tongue, (usually over another groups language) needed to be taught in the American public schools (Zimmerman, 2002). Newspaper pieces usually stressed the possibility of assimilation into mainstream America. Some local immigrant groups even took a grass roots approach by going house to house and having petitions signed by the community in support of their language cause. Jonathan Zimmerman says that in Chicago, "The Board of Education finally authorized the instruction of any language that the parents of twenty high schools students demanded" (Zimmerman, 2002). Ethnic newspapers and radio shows such as those found within the Polish, German, and Czech communities supported such efforts by asking it members to get involved and support the language cause.

Other groups like Greek immigrants would take a somewhat different approach. Rather than go through the bureaucracy of the public school system, Greek immigrants created their own privately funded Greek language schools. The schools operated as full day and evening schools. At the full day schools students learned Greek during the day and English in the afternoons. Evening students attended the Greek schools after their school day at their local public school. Andrew Kopan asserts, "For most Greek students however, the public school was crucial to their external adjustment and acculturation to American mainstream society." Greek children attending public schools were also enrolled in supplementary Greek schools and other private educational arrangements" (Kopan, 1975). Greek schools as Socrates and Koraes elementary schools in Chicago focused most of their educational attention on Greek language instruction-as it was seen that this was the best means to maintaining a Greek identity (Zervas, 2000).

In 1891, the National Education Association (NEA) supported the belief that all children in schools should only be instructed in English (Tyack, 1993). Many schools had allowed the teaching of some core subjects such as math and science in a foreign language. The NEA worried that permitting foreign language instruction would undermine the NEA's unique notion of Americanism. The NEA declared their opposition to foreign language instruction around the same time when immigrants from Eastern and Southeastern Europe were settling to the United States. These immigrants were from the poorer regions of Europe and their customs and traditions varied from their mostly Protestant Western European counterparts who were already settled in the United States. Arguably, it was more difficult for these groups to 
learn English. Their languages were linguistically farther displaced from a German, Scandinavian or Dutch speaker. Even the Irish had done away with Gaelic preferring English as their primary spoken language (Dublin, 1993). To make matters worse, for many anti-immigrant groups, the new incoming immigrants were mostly Catholics and Jews. It was feared by Protestant nativists groups that Catholics would one day dominate the American landscape, transforming the United States into a mostly Catholic nation. Feelings like these were present for most of the 1880's to early 1900s in most of America's metropolitan cities. Eventually, most of the foreign language instruction died down as immigration to the United States drastically slowed down in the 1920s when most of the world was suffering from the Great Depression.

\section{Taking Charge}

Undoubtedly, the new immigrants who were arriving were not satisfied with the already present modes of education in America. Many immigrants viewed the American school as heavily steeped in the Protestant tradition and feared that the public school sought to assimilate their children into mainstream Protestant America (Smith, 1969). John Rury says, "Catholics also objected to the principal of non-sectarianism, seeing the religious and moral content of non-Catholic schools as essentially Protestant" (Rury, 2005). Other groups saw the American public school as unorganized, bureaucratic and failing to accommodate the needs of the child. Catholic and Jewish immigrant groups responded by creating schools of their own to help curb the possibility of ethnic and religious assimilation and to guarantee a good education around notions of their religious traditions (Holli \& Jones, 1995). For example, by 1900 Irish Catholics had established a plethora of parish elementary and secondary schools in many American metropolitan cities where much of the Catholic population resided. The schools were often operated by the various Catholic religious orders (Rury, 2005). In another example in New York City, when Protestant schools decided to offer Hebrew language classes at their local Protestant schools the Jews of the city saw this as an attempt by Protestant America to proselytize Jewish children into adopting the Protestant faith (Cremin, 1988). The Jews rallied and organized to form their own schools where Hebrew was taught. Yeshiva and later Brandeis Universities would become the first Jewish universities to be modeled after the American secular university, intended for the Jewish-American student, but open to students of other faiths. Similarly, Georgetown, Notre Dame, Fordham, and St. Louis Universities would become America's earliest Catholic universities that catered to the needs of the Catholic student. Furthermore, all these universities found a successful market for the Catholic student seeking a private and Catholic oriented college education. Other Catholic universities as Loyola (1870) and DePaul (1898) Universities both located in Chicago were founded with the mission of educating immigrant students. Both universities welcomed both 
Catholic and non-Catholic students (Rury \& Suchar, 1998).

Many educational leaders were well aware that America's public schools were in need of a drastic curriculum overhaul. Immigration from Europe, migration from rural America into urban America, a quickly industrializing and growing America and a desire to educate the masses led to a report titled, Report of the Committee of the National Education Association in 1883. In the report, (better known as the Committee of Ten) a group of educational leaders outlined major changes to be considered for the high school curriculum. In broad terms, the curriculum sought to prepare students for college while at the same time the report considered a curriculum for students interested in entering the industrial workforce. David Tyack argues, "For the most part, the members of the Committee of Ten were college presidents and professors who wanted to bring some order to the hodgepodge of the high school curriculum and to standardize preparation for higher education" (Tyack, 1995). Nonetheless, the report would open a fierce discussion on what type of education was best fit for the diverse American student as well as how to prepare teachers to teach diverse student populations. Teachers College founded in 1887 in New York City recognized that the profession of teaching needed teachers who posed reliable knowledge about the conditions and circumstances under which students learned (Cremin, Shannon, \& Twonsend, 1954). Much of the teachers trained at the college incorporated this philosophy when teaching New York's immigrant population.

In the early 1890s, John Dewey would help propel what would be called the Progressive movement in education. Dewey, a Vermont native, who for most of his early career had little interaction with immigrant and diverse communities, understood that the social changes occurring in American society, warranted a change in the American curriculum (Martin, 2003). Social and technological forces such as industrialization, technological innovation as well as mass immigration would all inevitably reshape the American social fabric. For Dewey, it was important that the curriculum represent and present all the intrinsic factors in the human experience (Kliebard, 1986). In other words, to Dewey, the curriculum that was in place in most schools did not consider the needs of a diverse and multicultural America, but instead maintained an outdated outlook of how the white, Anglo Saxon, American child learned. For example, to Dewey the immigrant student and/or the industrial era student could not easily connect to subjects stepped in the humanist tradition such as Greek and Latin. More importantly, students generally were not connecting to the topics covered in more traditional subjects such as history, science, and literature. In the late 1890's at the Laboratory School at the University of Chicago, Dewey as the director of the school used a curriculum that catered to student interests (Cremin, 1988). Dewey's progressive school model would later be adopted by other school districts that had a large immigrant population. Dewey was at odds with Humanist, Progressives, and Traditionalist on what was the best curriculum for the American student. At other times, groups like Social Reconstructionist found harmony with Dewey's notion of considering the needs of diverse learners. 
Supporters of vocational education would also advocate reform in the curriculum. As noted by Herbert Kliebard, "Vocational education also fits perfectly into the social efficiency ideal of education as preparation for specific social and occupational role" (Kliebard, 1986). Advocates of vocational education insisted on a shift from apprenticeship to schooling on the basis of training the new immigrant practitioners for their specialties. The thrust of this debate was at the heart of the educational debate that later culminated into the Smith-Hughes legislation, which established federal funded programs for agricultural science, various trades, and home economics in the high school. Most of these programs would eventually benefit the immigrant student interested in entering the industrial and technical workforce.

Similarly, non-traditional modes of education or informal education could also be found in 1889 in Chicago at Jane Addam's Hull House. Often called the "Settlement", Hull House was organized to help the poor immigrant communities of the city find a job, a place to live, receive a basic education or learn a work related skill. One Italian immigrant woman mused,

Pretty soon they started the classes to teach us poor people to talk and write English. The talk of the people in the settlement house was different entirely than what I used to hear. I used to love those American people, and I was listening and listening how they talked. That's how I earned to talk such good English (Dublin, 1993).

Many adult immigrants as Rossa Cassettri flocked to Hull House to take English language courses when public schools did not offer adult education programs. Later, similar versions of Hull House appeared in other metropolitan cities across the United States.

\section{Conclusion}

The years 1880-1900 saw great waves of immigrants arriving to the United States. As the immigrants settled in America's urban centers, schools immediately set out to address the issue of diversity and how to educate a large diverse immigrant population. It is clear that most American schools set out to accommodate the new immigrant's educational needs while considering the unique immigrant perspective on education. Milton Gaither describes the immigrant as "a time traveler, a vestige of dying days magically transported through new technologies into the modern industrial state with no advanced preparation" (Gaither, 2003). Indeed, many of the new immigrants did not speak the language or understand the customs and traditions of their new country. Schools served the role of educating the immigrant populations and helping the immigrant settle comfortably into their new adopted land. When the schools were perceived as not being "accommodating" to the overall needs of the immigrant, immigrant communities often reacted by demanding such things as instruction in their native language, vocational training and adult 
educational programs. In other instances, when the immigrant community feared being assimilated into mainstream Americana they opened schools of their own, where their old ways could be preserved and blended into the ways of their new land. This essay set out to demonstrate how American schools between the years 1880-1900 set out to address issues of diversity and how various immigrant groups reacted to the already present modes of schooling in America's urban cities.

\section{References}

Bodnar, J. (1987). The Transplanted: A History of Immigrants in Urban America. Bloomington, IN: Indiana University Press.

Cremin, L. A. (1988). American Education: The Metropolitan Experience 1876-1980. New York, NY: Perennial Library.

Cremin, L. A., Shannon, D. A. \& Twonsend, M. E. (Eds.). (1954). A History of Teachers College, Columbia University. New York, NY: Columbia University Press.

Dublin, T. (1993). Immigrant Voices: New Lives in America, 1773-1986. Champaign Urbana, IL: University of Illinois Press.

Fass, P. S. (1989). Outside In: Minorities and the Transformation of American Education. Oxford, UK: Oxford University Press.

Gaither, M. (2003). American Education History Revisited: A Critique of Progress. New York, NY: Teachers College Press.

Gerstle, G. (1997). Liberty, Coercion, and the Making of Americans. Journal of American History, 84(3), 524-558.

Holli, M. G., \& Jones, P. A. (Eds.). (1995). Ethnic Chicago: A Multicultural Portrait. Grand Rapids, MI: William B. Erdmans Publishing Company.

Kliebard, Herbert M. (1986). The Struggle for the American Curriculum: 1893-1958. London, UK: Routledge.

Kopan, A. T. (1975). Education and Greek Immigrants in Chicago, 1892-1973: A Study in Ethnic Survival. Chicago, IL: Unpublished Dissertation.

Martin, J. (2003). The Education of John Dewey. New York, NY: Columbia University Press.

Olneck, M.R. (1989). Americanization and the education of Immigrants, 1900-1925: An Analysis of Symbolic Action. American Journal of Education, 97(4), 398-423.

Rury, J. L. (2005). Education and Social Change: Themes in the History of American Schooling. Mahwah, NJ: Lawrence Erlbaum Associates Publishers.

Rury, J. L., \& Suchar, C. S. (Eds.). (1988). DePaul University: Centennial Essays and Images. Chicago, IL: DePaul University.

Smith, T. L. (1969). Immigrant Social Aspirations and American Education, 18801930. American Quarterly, 21(3), 523-543

Tyack, D. B. (1993). Constructing Differences: Historical Reflection on Schooling and Social Diversity. Teachers College Record, 95(1), 8-34.

Tyack, D. B. (1995). Tinkering toward Utopia: A Century of Public School Reform. Cambridge, MA: Harvard University Press.

Zervas, T. G. (2000). Archaic Echoes of Archaic Teaching Techniques: An Interpretive Essay on the Instructional Implementation of the Socratic Method at the Koraes and Socrates' Schools. Evanston: IL: Unpublished Thesis.

Zimmerman, J. (2002). European Immigrants and Foreign Language Instruction. The Journal of American History, 88(4), 1383-1404. 